\title{
Aquatic invertebrate's distribution in a freshwater coastal lagoon of southern Brazil in relation to water and sediment characteristics
}

\author{
Distribuição de invertebrados aquáticos em uma lagoa costeira de água doce
} ao sul do Brasil em relação às características de água e sedimento

Leonardo Kleba Lisboa ${ }^{1,3}$, Aurea Luiza Lemes da Silva ${ }^{2,3}$ and Mauricio Mello Petrucio ${ }^{1,3}$

${ }^{1}$ Programa de Pós-Graduação em Biologia Vegetal, Universidade Federal de Santa Catarina - UFSC,

CEP 88010-970, Florianópolis, SC, Brazil

e-mail: leokleba@yahoo.com.br

${ }^{2}$ Programa de Pós-Graduação em Ecologia, Universidade de Brasília - UNB, Darcy Ribeiro,

CEP 70910-900, Brasília, DF, Brazil

e-mail: luizalemes@yahoo.com.br

${ }^{3}$ Laboratório de Ecologia de Águas Continentais, Universidade Federal de Santa Catarina - UFSC, CEP 88010-970, Florianópolis, SC, Brazil

e-mail: petrucio@ccb.ufsc.br

\begin{abstract}
Aim: The objective of this study was to evaluate the influence of water and sediment characteristics on the abundance, richness and diversity of the benthic invertebrate community in Peri lagoon, a freshwater coastal lagoon located in central coast of Santa Catarina State; Methods: Samplings were performed in April, May and June 2009, in five different sites of Peri lagoon. The samples were taken with an EckmanBirge drag, totalizing 60 for the invertebrate community, and 45 for sediment. Water physicochemical variables were also measured. Environmental influences in benthic community have been measured using a Canonical Correspondence Analysis (CCA). Linear regressions were also plotted for main correlations; Results: A total of 5,535 specimens were collected, identified into 18 taxa. Tanaidacea was the most abundant representing $54 \%$ of relative abundance, followed by Diptera $(23 \%)$, and Ostracoda $(17 \%)$. The richest family was Chironomidae with 6 taxa. CCA results indicated positive correlation between Chaoborus and Stenocypris with local depth, and negative correlation between Odonata, Gastropoda, Cytheridella and Coleoptera with the finest grains of sediment, as well as between Tanaidacea, Lopescladius, Annelida and Nematoda with both organic matter $(\mathrm{OM})$ content in sediment and local depth. Linear regression analysis demonstrated inverse relation of Tanaidacea in response to $\mathrm{OM}(\mathrm{y}=0.6-0.62 . \mathrm{OM})$ and sand ( $\mathrm{y}=0.6-0.6$.sand), and of Lopescladius in response to OM ( $\mathrm{y}=0.37-0.41$. $\mathrm{OM})$ and sand $(\mathrm{y}=0.37-0.46$.sand). The fact that Peri lagoon has no marine influence and has Tanaidacea as the most abundant taxa, a group not expected in freshwaters, gives to this lagoon a particular relevance among coastal lagoons. The study concluded that sediment characteristics and local depth are more significant than water variables in determining the benthic community structure in Peri lagoon, which varied in accordance with different local conditions.
\end{abstract}

Keywords: benthic community, richness and diversity, lentic system.

Resumo: Objetivo: O objetivo deste estudo foi avaliar a influência das características da água e sedimento na abundância, diversidade e riqueza da comunidade de invertebrados bentônicos na lagoa do Peri, uma lagoa costeira de água doce localizada em Santa Catarina. Métodos: Foram realizadas 60 coletas para análise de invertebrados, e 45 para sedimento entre abril, maio e junho de 2009, em 5 diferentes pontos da lagoa com draga EckmanBirge. Variáveis físicas e químicas da água também foram medidas. A influência dos fatores ambientais na comunidade foi medida através de uma Análise de Correspondência Canônica (CCA), e foram feitas regressōes lineares para as principais correlaçóes; Resultados: Um total de 5,535 espécimes foram coletados, identificados em 18 táxons. Tanaidacea foi o mais abundante representando $54 \%$ da abundância relativa, seguido de Diptera (23\%) e Ostracoda (17\%). A família mais rica em gêneros foi Chironomidae (6 táxons). Os resultados da CCA revelaram correlação positiva entre Chaoborus e Stenocypris com a profundidade local, e negativa entre Odonata, Gastropoda, Cytheridella e Coleoptera com gráos finos, assim como entre Tanaidacea, Lopescladius, Annelida e Nematoda com a quantidade de matéria orgânica $(\mathrm{MO})$ no sedimento e profundidade 
local. Regressóes lineares demonstraram uma relação inversa de Tanaidacea em resposta a $\mathrm{MO}(\mathrm{y}=0.6-0.62 \mathrm{MO})$ e areia grossa $(\mathrm{y}=0.6-0.6$ are $)$ assim como de Lopescladius em relação a $\mathrm{MO}(\mathrm{y}=0.37-0.41 \mathrm{MO})$ e areia grossa $(\mathrm{y}=0.37-0.46$.are $)$. $\mathrm{O}$ fato da lagoa do Peri não ter influência do mar e ter Tanaidacea como táxon mais abundante, um grupo não esperado em ambientes de água doce, lhe confere destaque entre demais lagoas costeiras do Brasil. Através deste estudo concluímos que as características de sedimento e profundidade local foram mais importantes que variáveis da água na determinação da estrutura da comunidade de invertebradoss bentônicos na lagoa do Peri, que variou de acordo com características ambientais locais.

Palavras-chave: comunidade bentônica, riqueza e diversidade, sistema lêntico.

\section{Introduction}

Benthic invertebrates are a component of aquatic communities with a large distribution and a strong interaction with environmental conditions (Moretti and Callisto, 2005; Würdig et al., 2007). They play a key role in the nutrient cycling and energy flow of aquatic environments, acting in organic matter breakdown process and taking effectively part in ecosystems biogeochemical cycles (Covich et al., 1999; Strixino and Trivinho-Strixino, 2006). This faunal component has been frequently used in environmental quality assessment (Guimarães et al., 2009; Mugnai et al., 2010).

This community shows a different distribution in space and time, varying in accordance with water physical-chemical conditions (Pereira and De Luca, 2003), substrate type and organic matter content in sediment (Covich et al., 1999), influence of macrophytes (Kevrekidis, 2004), and local depth (Pamplin and Rocha, 2007). Because the environmental heterogeneity, these variables may differ in distinct areas of lakes, wetlands and streams, determining changes in the structure and distribution of benthos (Würdig et al., 2007).

Considering the aquatic ecosystems in general, the coastal lagoons and estuaries demonstrate a strong interaction between benthos and the water column (Bemvenuti and Rosa-Filho, 2000). Additionally, these environments provide nursery habitats for various species (Almeida et al., 2008). These ecosystems are complex environments that experience large fluctuations in abiotic variables associated with drastic changes in the structure of assemblages (Carvalho et al., 2011). Nevertheless, there is no general consensus on which environmental variables are more important in structuring invertebrate assemblages in these ecosystems. Many studies have shown that salinity is the most important factor determining the benthic community structure (Gamito, 2006; Pech et al., 2007; Almeida et al., 2008). There is, however, a lack of studies about coastal lagoons that act as reservoirs, and benthic communities are still poorly understood.

We studied the structure and composition of the benthic invertebrate community in Peri lagoon, a subtropical coastal lagoon which acts as a freshwater reservoir, aiming to examine the correlation between these community and particular characteristics of water and sediment.

\section{Material and Methods}

\subsection{Study area}

Peri lagoon $\left(27^{\circ} 44^{\prime} \mathrm{S}\right.$ and $\left.48^{\circ} 31^{\prime} \mathrm{W}\right)$ is located in the southern region of the Florianópolis island, central coast of Santa Catarina (Figure 1). The lagoon's surface area of $5.7 \mathrm{~km}^{2}$ is surrounded by mountains covered with well preserved Atlantic Rain Forest in the northern, western and southern portions, and by "restinga" vegetation in the eastern portion. The climate in the area is characteristically subtropical, with rainfall well distributed along the year, but concentrated in spring and summer months (October-March) (Hennemann and Petrucio, 2010)

Peri lagoon is a freshwater coastal lagoon without marine influences (freshwater all over the year), making from it the main freshwater resource in the Florianópolis's island. A water supply network is working at the lagoon with mean capacity of $200 \mathrm{~L} / \mathrm{s}$, providing water for five districts of the municipality. Thus, almost the entire area of the Peri Lagoon Watershed is situated within an environmentally protected area since 1981, with restricted human occupation.

\subsection{Data sampling}

Samplings were carried out three times, respectively in April, May and June 2009. Five different sites were chosen in Peri Lagoon (Figure 1). The samples sites were selected considering an adequate representation of the different parts of the 


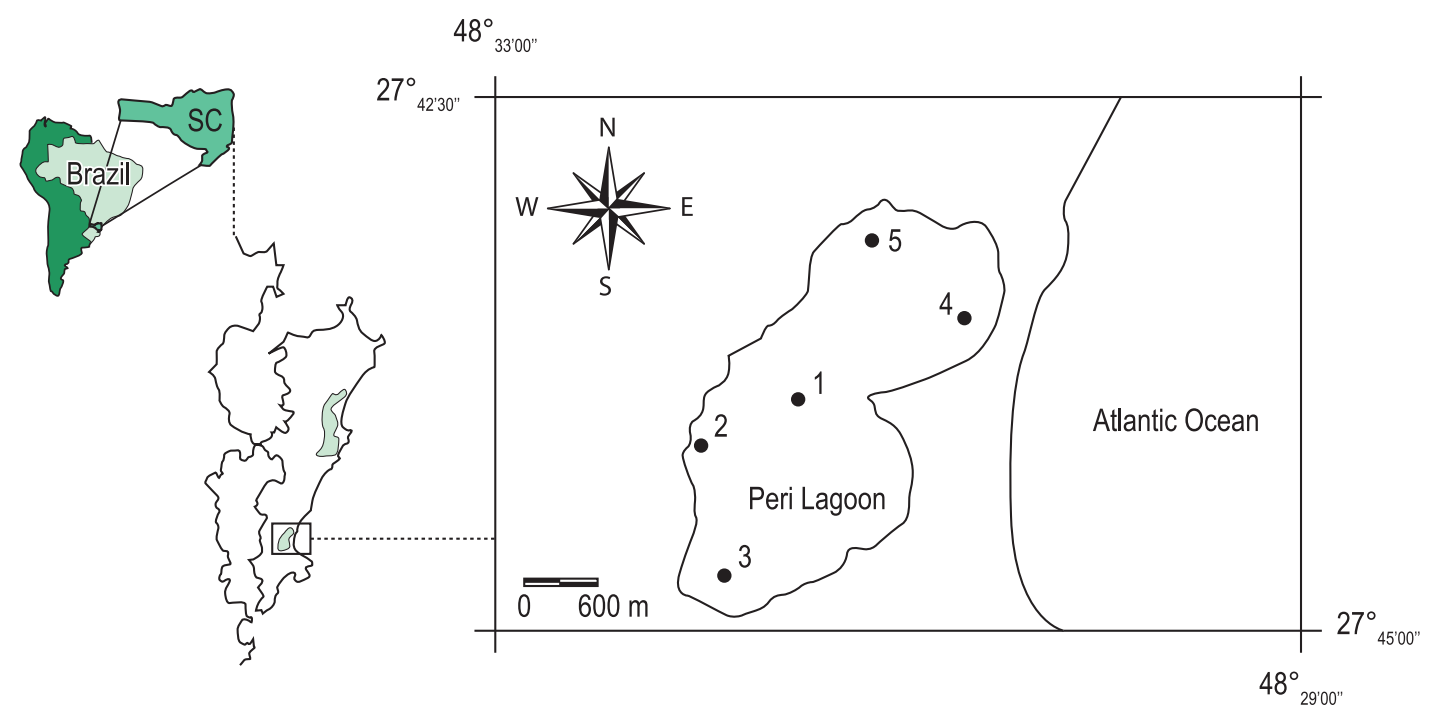

Figure 1. The map of the sampling sites in Peri lagoon ( $27^{\circ} 44^{\prime} \mathrm{S}$ and $\left.48^{\circ} 31^{\prime} \mathrm{W}\right)$, southern region of Florianópolis Island (Santa Catarina, Brazil).

lagoon, ranging the northern (P5), central (P1) and southern (P3) regions, and describing deep (P1) and shallow (P4) areas, both in a mouth of rivers (P2 and $\mathrm{P} 3$ ) or in other areas (P5, P4, P1) (Figure 1).

In each sampling site four samples using an Ekman-Birge grab $(15 \times 15 \mathrm{~cm})$ were taken for invertebrate analyses, and three samples for sediment analyses (mean grain size and percentage of organic matter), totalizing 105 samples in the studied period. The samples were washed under running water using $250 \mu \mathrm{m}$ mesh sieves, and all invertebrates retained were sorted, counted and preserved in $70 \%$ ethanol. The aquatic fauna were sorted under stereo microscope and identified to the lowest possible taxonomic level using identification keys by Fernández and Domínguez (2001) and Mugnai et al. (2010). The organisms belonging to the Chironomidae family were mounted on semipermanent slides and subsequently identified under stereomicroscope, according to Trivinho-Strixino and Strixino (1995).

Water was collected in Sechis disc depth for analyses. The water temperature $\left({ }^{\circ} \mathrm{C}\right)$, conductivity $\left(\mu \mathrm{S} . \mathrm{cm}^{-1}\right), \mathrm{pH}$ and dissolved oxygen $\left(\mathrm{mg} . \mathrm{L}^{-1}\right)$ were measured in situ at each sampling station with the specific probe WTW-Multi 350i. Local depth $(\mathrm{m})$ was also measured. The granulometric composition of the sediment was determined by sieving in laboratory, and grain size was classified into 3 size classes according to the granulometric scale of Suguio (1973). Organic matter content was determined by ignition ( $7 \mathrm{~g}$ of sediment burnt at $550{ }^{\circ} \mathrm{C}$ during 4 hours).

\subsection{Data analyses}

The statistical treatment was made considering the mean values of the three months together, and all data were log transformed prior to analyses. The work was carried out using community mean densities (ind. $225 \mathrm{~cm}^{-2}$ ) and environmental parameters, which were normalized using Primer 6 Beta software. Univariate analyses of variance (ANOVA) were used to test for differences in the environmental measured parameters of water and sediment, and in invertebrate community densities between the sampling sites. Pearson Correlation coefficients " $r$ " were used to identify significant correlations between community taxa and environmental variables. Stepwise regressions were used to illustrate the response of main community taxa to their main environmental variables. The relationship between environmental variables and invertebrate community structure was explored by means of a Canonical Correspondence Analysis (CCA) biplot distribution, tested with Mont Carlo significance levels, using Canoco for Windows 4.5 software. ANOVA, Pearson's "r", and linear regressions were calculated using Statistica 7 software.

\section{Results}

The summary of environmental variables values of water and sediment measured in the five sampling sites is presented in Table 1. Depth was higher in P1, with a maximum of $9 \mathrm{~m}$ in April, and it achieved 
Table 1. Mean values and standard deviation (in parenthesis) of environmental variables of water and sediment measured at the five sites in Peri lagoon during the three samples moments.

\begin{tabular}{lrrrrr}
\hline \multicolumn{1}{c}{ Variables } & \multicolumn{1}{c}{ P1 } & \multicolumn{1}{c}{ P2 } & \multicolumn{1}{c}{ P3 } & \multicolumn{1}{c}{ P4 } & \multicolumn{1}{c}{ P5 } \\
\hline Depth $(\mathrm{m})$ & $8.41(0.52)$ & $2.55(0.43)$ & $2.13(0.23)$ & $1.50(0.23)$ & $2.15(0.35)$ \\
Ph & $6.96(0.14)$ & $7.00(0.21)$ & $7.03(0.14)$ & $6.93(0.14)$ & $6.85(0.24)$ \\
Dissolved oxigen $\left(\mathrm{mg}^{\circ} \mathrm{L}^{-1}\right)$ & $8.42(0.70)$ & $8.51(0.55)$ & $8.39(0.79)$ & $8.36(0.63)$ & $8.38(0.65)$ \\
Water temperature $\left({ }^{\circ} \mathrm{C}\right)$ & $21.36(4.06)$ & $21.86(4.11)$ & $22.00(3.82)$ & $21.73(4.45)$ & $20.83(3.70)$ \\
Conductivity $\left(\mu \mathrm{s} \mathrm{Cm}^{-1}\right)$ & $69.46(3.42)$ & $71.46(0.65)$ & $71.53(0.93)$ & $71.40(0.62)$ & $70.53(2.43)$ \\
Orgânic mater $(\%)$ & $30.34(3.19)$ & $35.12(3.67)$ & $26.3(3.53)$ & $3.45(3.56)$ & $3.84(2.28)$ \\
Sand $(\%)$ & $11.97(1.27)$ & $32.22(6.05)$ & $19.30(3.79)$ & $3.59(0.66)$ & $26.68(5.04)$ \\
Clay $(\%)$ & $15.09(1.49)$ & $23.46(3.81)$ & $17.95(1.46)$ & $17.40(0.32)$ & $19.86(2.34)$ \\
Silt $(\%)$ & $72.25(1.74)$ & $44.23(7.52)$ & $61.92(5.11)$ & $78.76(0.95)$ & $52.25(6.99)$ \\
\hline
\end{tabular}

the minimum value in $\mathrm{P} 4$ with $1.3 \mathrm{~m}$, measured in the same month.

Water variables ( $\mathrm{pH}$, dissolved oxygen, temperature and conductivity) did not show significant differences between the sampling sites $(\mathrm{F}=0.5, \mathrm{p}=0.91)$. Water temperature showed $\mathrm{a}$ decreasing tendency along the sampling months due to the subtropical climate. Oxygen concentrations have presented an inverse tendency to water temperature, in which the concentrations increased with the decrease of the last.

The organic matter percentages in sediment were higher in P2 and P1 (35.12 and 30.34\%), and smaller in P4 and P5 (3.45 and 3.84\%). Sediment of Peri lagoon was quite heterogeneous in relation to the granulometric composition, with mean values of sand ranging from $3.59 \%$ in site $\mathrm{P} 4$ to $32.22 \%$ in site $\mathrm{P} 2$, and mean values of silt ranging from $44.23 \%$ in site $\mathrm{P} 2$ to $78.76 \%$ in site P4 (Table 1). ANOVA showed significant differences of granulometric composition and organic matter contents in sediment among the sampling sites $(\mathrm{F}=2.89, \mathrm{p}=0.01)$.

The aquatic invertebrate community was described on the basis of mean densities (ind $\mathrm{m}^{-2}$ ), taxonomic richness and relative abundance (Table 2). A total of 5,535 specimens of fauna were collected in the sediment, distributed in 18 taxa and 6 classes. Chironomidae was the more diverse taxa, presenting 6 genus (Table 2). Crustacea was the numerically dominant taxa, representing more than $70 \%$ of the community, where the group Tanaidacea showed $54.2 \%$ of these amount, and Ostracoda $17.4 \%$. The second most abundant group was Diptera, representing more than $23 \%$ of the relative abundance, mainly with the genus of the Chironomidae Lopescladius (8.3\%), Chironomus (6.7\%) and Coelotanypus (4.6\%).

Invertebrate community composition and abundance in Peri lagoon varied significantly among the sampling sites $(\mathrm{F}=5.16, \mathrm{p}=0.03)$. Total abundance and species richness between the five sampling sites ranged from 201 individuals in P5 and 9 taxa in P3 to 4,131 individuals and 14 taxa in P4. In the central site (P1) Ostracoda predominated with the highest abundance, followed by Chaoborus. In the two southern sites (P2 and P3) Chironomus predominated followed by the ostracode Cytheridella ilosvayi Daday, 1905. In site P4 Tanaidacea was the predominant taxa, and in the northern site (P5) Chironomus and Coelotanypus predominated.

Tanaidacea densities found in Peri lagoon were extremely high in $\mathrm{P} 4$, reaching more than 10,000 individuals per $\mathrm{m}^{-2}$, despite the low densities observed in others sites. C. ilosvayi was also present in high density in $\mathrm{P} 3$, reaching $1,818.5$ ind. $\mathrm{m}^{-2}$, and the quironomid Lopescladius presented a density of $1,655.5$ ind. $\mathrm{m}^{-2}$ also in P4. The lowest density among sample sites were observed in P5 with 744.4 ind. $\mathrm{m}^{-2}$, and the highest one was observed in $\mathrm{P}$, which presented 15,300 ind. $\mathrm{m}^{-2}$.

According to the CCA between the mean environmental variables and community densities of the five different sampling sites, the main environmental variables that determined the community structure were organic matter content in sediment, coarse grains and water depth (Table 3). The first two components of CCA explained $61.4 \%$ of total community variability (Figure 2 ). The first axis accounted with 36.1\% (Monte Carlo test $\mathrm{p}$-value $=0.002)$ and the second accounted with others 25.3\% (Monte Carlo significances test of all canonical axes $\mathrm{p}$-value $=0.03$ ).

In accordance with CCA analysis, it was possible to observe that Chaoborus and Stenocypris major Baird, 1859 were positively correlated with water depth. In the other hand, Annelida and Tanaidacea were negatively correlated with this variable, and they also showed to be negatively correlated with 
Table 2. Taxonomic composition, mean density of organisms at each sample site and relative abundance of aquatic invertebrates found in the sediment of Peri lagoon during the three samples moments.

\begin{tabular}{|c|c|c|c|c|c|c|c|}
\hline & \multicolumn{6}{|c|}{ Mean density (m-2) } & \multirow{2}{*}{$\begin{array}{c}\text { Relative } \\
\text { abundance \% }\end{array}$} \\
\hline \multicolumn{2}{|c|}{ TAXA } & P1 & P2 & P3 & P4 & P5 & \\
\hline \multirow{2}{*}{\multicolumn{8}{|c|}{$\begin{array}{l}\text { ARTHROPODA } \\
\text { Insecta }\end{array}$}} \\
\hline & & & & & & & \\
\hline \multicolumn{8}{|l|}{ Diptera } \\
\hline Chironomidae & pupa & 51.9 & 29.6 & 3.7 & 33.3 & & 0.6 \\
\hline \multirow[t]{2}{*}{ Chironominae } & Stempellina & & & & 33.3 & & 0.2 \\
\hline & Chironomus & 151.9 & 377.8 & 263.0 & 285.2 & 288.9 & 6.7 \\
\hline \multirow[t]{3}{*}{ Tanypodinae } & Coelotanypus & 166.7 & 66.7 & 59.3 & 477.8 & 163.0 & 4.6 \\
\hline & Djalmabatista & & & & 125.9 & & 0.6 \\
\hline & Labrundinae & & & & 59.3 & & 0.3 \\
\hline Orthocladiinae & Lopescladius & 25.9 & 7.4 & & $1,655.6$ & 14.8 & 8.3 \\
\hline Chaoboridae & Chaoborus & 277.8 & 11.1 & & 92.6 & 22.2 & 2.0 \\
\hline \multicolumn{8}{|l|}{ Odonata } \\
\hline Gomphidae & Gomphoides & 7.4 & 25.9 & 14.8 & 3.7 & 14.8 & 0.3 \\
\hline Libellulidae & & & 7.4 & & & & 0.0 \\
\hline \multicolumn{8}{|l|}{ Coleoptera } \\
\hline Elmidae & & & 7.4 & 11.1 & & & 0.1 \\
\hline \multicolumn{8}{|l|}{ Trichoptera } \\
\hline Calamoceratidae & & 18.5 & 18.5 & & 44.4 & 3.7 & 0.4 \\
\hline \multicolumn{8}{|l|}{ Ostracoda } \\
\hline Cytheridae & Cytheridella ilosvayi & 392.6 & 125.9 & $1,818.5$ & 911.1 & 3.7 & 15.9 \\
\hline Cyprididae & Stenocypris major & 248.1 & & 7.4 & 44.4 & & 1.5 \\
\hline \multicolumn{8}{|l|}{ Malacostraca } \\
\hline Tanaidacea & & 7.4 & 29.6 & 3.7 & $10,985.2$ & 77.8 & 54.2 \\
\hline Acari & & & 3.7 & & & 18.5 & 0.1 \\
\hline \multicolumn{8}{|l|}{ ANNELIDA } \\
\hline Oligochaeta & & 25.9 & 22.2 & 81.5 & 381.5 & 100.0 & 3.0 \\
\hline \multicolumn{8}{|l|}{ MOLLUSCA } \\
\hline Gastropoda & & & 37.0 & 14.8 & & 22.2 & 0.4 \\
\hline NEMATODA & & 18.5 & 3.7 & & 166.7 & & 0.9 \\
\hline Total & & $1,392.6$ & 781.5 & $2,281.5$ & $15,300.0$ & 744.4 & 100.0 \\
\hline
\end{tabular}

Table 3. Inter set correlation values of environmental variables with the fisrt two axes of CCA.

\begin{tabular}{llrrrrrrrr}
\hline & Depth & \multicolumn{1}{c}{$\mathrm{pH}$} & \multicolumn{1}{c}{$\mathrm{O}_{2}$} & \multicolumn{1}{c}{$\mathrm{T}^{\circ} \mathrm{C}$} & Conductivity & \multicolumn{1}{c}{$\mathrm{OM}$} & \multicolumn{1}{c}{ Sand } & \multicolumn{1}{c}{ Clay } & \multicolumn{1}{c}{ Silt } \\
\hline Axis 1 & 0.5551 & 0.3546 & 0.4193 & -0.3236 & -0.2698 & 0.7906 & 0.6945 & 0.0861 & -0.4753 \\
Axis 2 & 0.7646 & -0.1002 & -0.1525 & 0.08 & -0.3366 & 0.1293 & -0.0516 & -0.3918 & 0.3502 \\
\hline
\end{tabular}

organic matter content in the sediment, while Chironominae showed to be positively correlated with this variable.

The groups Trichoptera and Tanypodinae demonstrated a positive correlation with water temperature and silt particles of the sediment. In the other hand, Gomphidae and C. ilosvayi, and even Gastropoda, Libellulidae and Coleoptera showed to be negatively correlated with the finest particles of the sediment (silt), and demonstrated a positive correlation with sand, clay, and water oxygen concentrations (Figure 2).
Figure 3 illustrate the responses of Tanaidacea, that represents the most abundant taxa of the lagoon, and Lopescladius, that represents the main quironomid genus, to organic matter content and percentage of sand in sediment, respectively the main environmental variables that structured these groups. The Pearson's correlation coefficient for these taxa was calculated against all environmental variables, considering only significant $(\mathrm{p}<0.05)$ variables for each taxa to make the regressions.

For the tanaids group, organic matter content in sediment was a core explanatory factor $\left(r^{2}=0.44\right.$, 
$\mathrm{p}=0.007)$ with negative correlation. We found evidence that the percentage of sand in sediment is also determinant for the variation of these group, showing a direct negative relation with tanaids density $\left(r^{2}=0.42, p=0.009\right)$. The most abundant

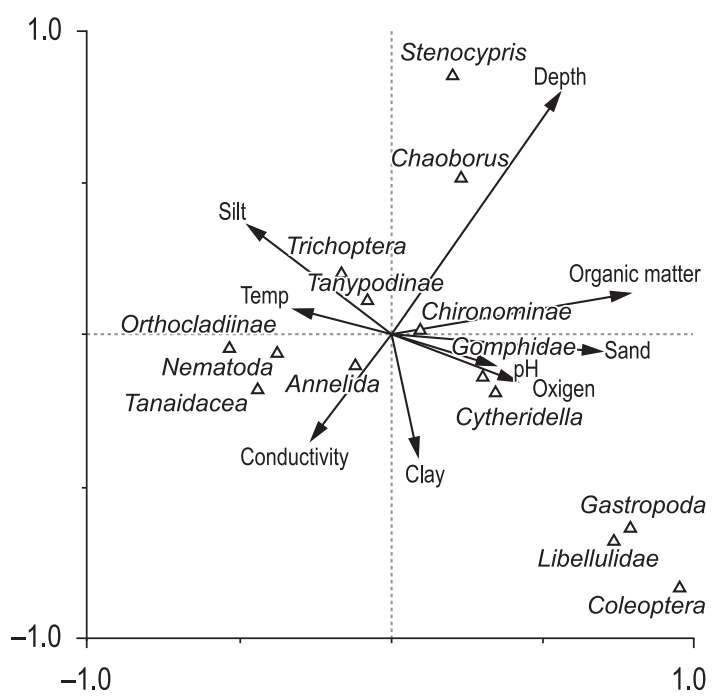

Figure 2. Graphical results of Canonical Correspondence Analysis (CCA) biplot ordination on the basis of the environmental variables and invertebrates community observed in Peri lagoon during the study. The first axis correspond with $36.1 \%$ of the explanation of variation, and the second axis with $25.3 \%$.
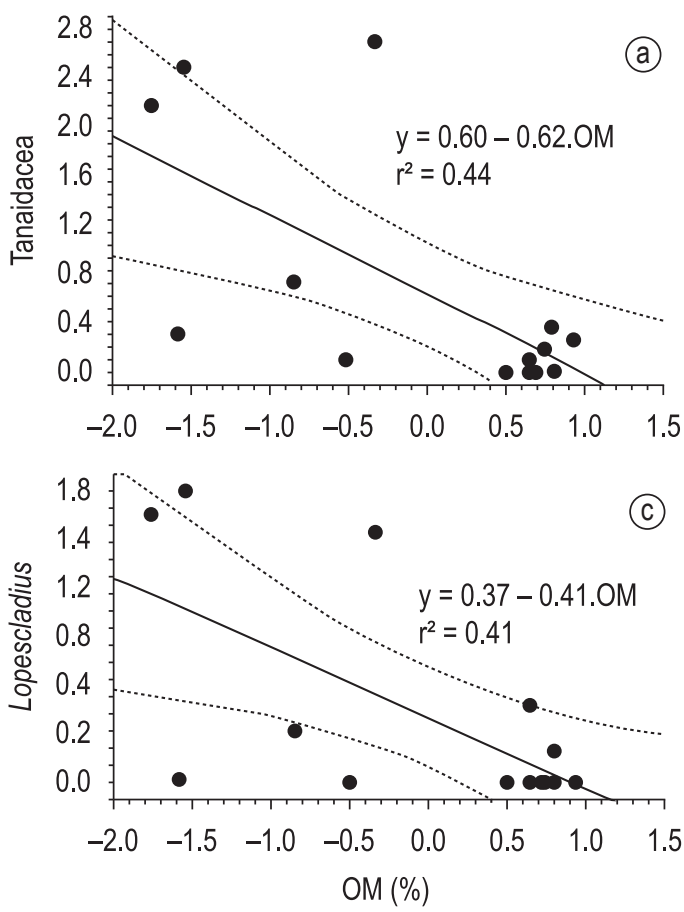

quironomid genus (Lopescladius) has shown a negative correlation with OM content $\left(\mathrm{r}^{2}=0.41\right.$, $\mathrm{p}=0.01)$ and sand percentage $\left(\mathrm{r}^{2}=0.54, \mathrm{p}=0.001\right)$ in sediment, this last one explaining more than $50 \%$ of its variability (Figure 3).

\section{Discussion}

Among the measured environmental variables of Peri lagoon, organic matter percentage in sediment, granulometric composition and local depth explained the largest proportion of the structure and distribution of benthic community. This was subjected to the spatial variability of physics and chemical variables of the lagoon, primarily to the characteristics of sediment and local depth. In fact, studies on lentic ecosystems came to the conclusion that environmental factors such as organic matter content in sediment (Würdig et al., 1998; Cartier et al., 2010) and grain sizes (Cenzano and Würdig, 2006; Würdig et al., 2007) are considered explanatory variables for density and distribution of benthic community. In the other hand, size and habitat structure seems to play an important role on invertebrate community composition (Heino, 2000), and even water temperature and influence of macrophytes could have a key role structuring this community (Kevrekidis, 2004).
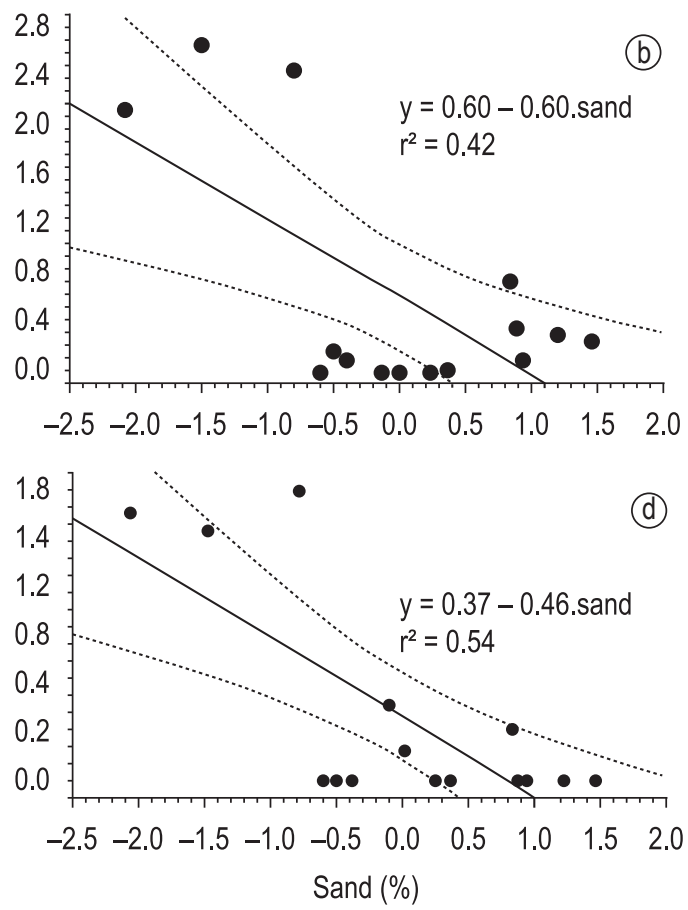

Figure 3. Responses of Tanaidacea to OM (a) and sand (b), and Lopescladius to OM (c) and sand (d) with regressions fit equations and $\mathrm{r}^{2}$ values. It was considered the mean density $\left(225 \mathrm{~cm}^{-2}\right)$ of the taxa $\log (\mathrm{n}+1)$ transformed, and abiotic variables $\log (\mathrm{x})$ transformed. Dashed lines represents $95 \%$ confidence interval. Straight fits in all cases are significant $(\mathrm{p}<0.05)$. 
In coastal lagoons, however, many studies show that salinity is a key factor in regulating benthic community, assigning secondary role to sediment granulometric composition and organic matter content (Gamito, 2006; Pech et al., 2007; Almeida et al., 2008). Notwithstanding, Peri lagoon is situated among the infrequent coastal lagoons with no marine influence, besides its proximity to the Atlantic Ocean. The presence of Tanaidacea is a fact that corroborates this ambiguity of influences. According to Jaume and Boxshall (2008), tanaids are essentially marines, and worldwide represented in freshwater systems only with four species. In addition, in South America occurs only one species (Jaume and Boxshall, 2008). These observations make from Peri lagoon a conspicuous case. Being one of the first studies ever made on benthic communities to the Peri lagoon, we were able to demonstrate a presence of more than $50 \%$ of the relative abundance composed by tanaids. This dominance of crustaceans was already observed in other Brazilian coastal lagoons, being also tanaids one of the most abundant groups in Taim Hydrological System (Würdig et al., 2007). According to Würdig et al. (2007), a historical process of ecological and large temporal scale explains the presence of these taxa in these systems. In addition, Covich et al. (1999) have shown that crustaceans play important roles in aquatic ecosystems, mainly on detritivorous food web.

The water supply network located in Peri lagoon must ensure a good water quality without salinity, making from this coastal lagoon also a reservoir with a constructed barrier to control the water level. In spite of this consideration, we argue that Peri lagoon differs from other man-made reservoirs, that have the water level flow and regime controlled according to human necessities and are dominated by Oligochaeta and Diptera (Pamplin et al., 2006; Pamplin and Rocha, 2007). Peri lagoon has most of its dynamics governed by nature, and a community that is closer related to those of others coastal lagoons (Würdig et al., 2007). Working with semi-natural coastal lagoons in Southern Portugal, Gamito (2006) found a similar community characteristic of estuarine and shallow-water habitats, but in this case dominated by mollusks and Chironomidae. In the same direction, Kevrekidis (2004) observed low salinities Mediterranean coastal lagoons dominated by mollusks and amphipods.

The highest zoobenthos abundance in Peri lagoon was observed at the shallowest sites, in accordance with Cenzano and Würdig (2006) and Cartier et al. (2010). The low dominance of Annelida (3\% of the relative abundance), compared with the findings of Cenzano and Würdig (2006) and Würdig et al. (2007) in other Brazilians coastal lagoons, may attest the good quality of the lagoon ecosystem. Hypothetically, it could also be considered if the low dominance of Annelida presents a correlation to oligotrophic for nutrients concentrations, as shown by Hennemann and Petrucio (2010).

Evident correlation between Chaoborus and water depth observed in this study has been established in many others studies of lentic environments (Arcifa, 2000; Bezerra-Neto and Pinto-Coelho, 2002; Pamplin and Rocha, 2007), and could be explained by the natural behavior of this group (Bezerra-Neto and Pinto-Coelho, 2002). Nevertheless, it was Stenocypris major that showed the strongest correlation with water depth, and studies about this interaction are infrequent. Oligochaeta was negatively correlated with water depth, what was already observed by Pamplim and Rocha (2007), and may be explained by a better adaptation of these group in the site with the greatest density of organisms.

The direct negative relationship of Tanaidacea and Lopescladius, respectively the first and the third most important components of benthos densities, with $\mathrm{OM}$ and sand content in sediment, suggests that an organic enrichment in this system could promote drastic changes in the composition and abundances of aquatic invertebrate community in the entire lagoon. Nevertheless, few studies with these groups were performed in Brazilian freshwater systems, and their real importance is still by far unknown.

The present study intended solely to correlate the aquatic invertebrate community with water and sediment's characteristics of the lagoon. Many other variables play also a role in the community structure, such as influence of macrophytes (Kevrekidis, 2004; Albertoni et al., 2007), predation intensity (Marques et al., 1999), habitat stability (Herbst and Bromley, 1984), water renewal regimes (Gamito, 2006) and temporal and spatial dynamics (Carvalho et al., 2011). A biogeographycal multiscale approach could also be taken into account (Ricklefs and Schulter, 1993).

Even with the great importance of invertebrates in nutrient's cycling and ecological successional process of aquatic ecosystems, few studies have been made with these organisms in freshwater coastal lagoons. Despite the punctual empirical 
focus of this study, we expect to have contributed to advance a few steps on the knowledge about the benthic invertebrates, especially about the role of Tanaidaceae in freshwater coastal ecosystems.

\section{Acknowledgements}

The authors would especially like to thank the Laboratório de Biologia e Cultivo de Peixes de Água Doce (LAPAD), which has provided the boat and technical support for all the samplings. We would also like to thank the Federal University of Santa Catarina (UFSC) and the Biological Science Center (CCB) for the scholarship and structure.

\section{References}

ALBERTONI, EF., PERLLVITZ, LJ. and PALMASILVA, C. 2007. Macroinvertebrate fauna associated with Pistia stratiotes and Nymphoides indica in subtropical lakes (south Brazil). Brazilian Journal of Biology, vol. 67, no. 3, p. 499-507. http://dx.doi. org/10.1590/S1519-69842007000300015

ALMEIDA, C., COELHO, R., SILVA, M., BENTES, L., MONTEIRO, P., RIBEIRO, J., ERZINI, K. and GONÇALVES, JMS. 2008. Use of different intertidal habitats by faunal communities in a temperate costal lagoon. Estuarine, Costal and Shelf Science, vol. 80, no. 3, p. 357-364. http://dx.doi. org/10.1016/j.ecss.2008.08.017

ARCIFA, MS. 2000. Feeding habits of Chaoboridae larvae in a tropical Brazilian reservoir. Revista Brasileira de Biologia, vol. 60, no. 4, p. 591-597. http://dx.doi. org/10.1590/S0034-71082000000400008

BEMVENUTI, CE. and ROSA-FILHO, JS. 2000. Estrutura e dinâmica das associaçóes de macroinvertebrados bentônicos dos ambientes estuarinos do Rio Grande do Sul: um estudo de caso. In Anais do Workshop: Avaliação e Açóes Prioritárias para a Zona Costeira e Marinha, 2000. PROBIO. 49p.

BEZERRA-NETO, JF. and PINTO-COELHO, RM. 2002. Migração vertical das larvas de Chaoborus brasiliensis (Theobald 1901) (Diptera, Chaoboridae) em um reservatório tropical: Lagoa do Nado, Belo Horizonte, estado de Minas Gerais. Maringá, vol. 24, no. 2, p. 329-336.

CARTIER, V., CLARET, C., GARNIER, R., FAYOLLE, S. and FRANQUET, E. 2010. Multi-scale approach to the environmental factors effects on spatiotemporal variability of Chironomus salinarius (Diptera: Chironomidae) in a French coastal lagoon. Estuarine, Coastal and Shelf Science vol. 86, p. 637644. http://dx.doi.org/10.1016/j.ecss.2009.11.031

CARVAlHO, S., PEREIRA, P., PEREIRA, F., PABLO, H., VALE, C. and GASPAR, MB. 2011. Factors structuring temporal and spatial dynamics of macrobenthic communities in a eutrophic coastal lagoon (Óbidos lagoon, Portugal). Marine Environmental Research, vol. 71, p. 97-110. PMid:21236484. http://dx.doi.org/10.1016/j. marenvres.2010.11.005

CENZANO, CSS. and WÜRDIG NL. 2006. Spatial and temporal variations of the benthic macrofauna in different habitats of a lagoon of the northern coastal system of Rio Grande do Sul State, Brazil. Acta Limnologica Brasiliensis, vol.18, no. 2, p. 153-163.

COVICH, AP., PALMER, AM. and CROWL TA. 1999 The Role of Benthic Invertebrate Species in Ecossystems: Zoobenthic species influence energy flows and nutrient cycling. BioScience, vol 49, no. 2, p. 119-127.

FERNÁNDEZ, HR. and DOMINGUÉZ, E. 2001. Guia para determinación de los artropodos bentônicos Sudamericanos. Tucumán: UNT. 282 p.

GAMITO, S. 2006. Benthic ecology of semi-natural coastal lagoons, in the Ria Formosa (Southern Portugal), exposed to different water renewal regimes. Hidrobiologia, vol. 555, p. 75-87. http://dx.doi. org/10.1007/s10750-005-1107-3

GUIMARÁES, RM., FACURE, KG., PAVANIN, LA. and JACOBUCCI, GB. 2009. Water quality characterization of urban streams using benthic macroinvertebrates community metrics. Acta Limnologica Brasiliensis, vol. 21, p. 217-226.

HEINO, J. 2000. Lentic macroinvertebrate assemblage structure along gradients in spatial heterogeneity, habitat size and water chemistry. Hydrobiologia, vol. 418, p. 229-242. http://dx.doi. org/10.1023/A:1003969217686

HENNEMANN, MC. and PETRUCIO, MM. 2010. Spatial and temporal dynamic of trophic relevant parameters in a subtropical coastal lagoon in Brazil. Environmental Monitoring and Assessement, vol. 181, no. 1-4, p. 347-361. http://dx.doi.org/10.1007/ s10661-010-1833-5

HERBST, GN. and BROMLEY, HJ. 1984. Relationships between habitat stability, ionic composition, and the distribution of aquatic invertebrates in the desert regions of Israel. Limnology Oceanography, vol. 29, no. 3, p. 495-503. http://dx.doi.org/10.4319/ lo.1984.29.3.0495

JAUME, D. and BOXSHALL, DA. 2008. Global diversity of cumaceans \& tanaidaceans (Crustacea: Cumacea \& Tanaidacea) in freshwater. Hydrobiologia, vol. 595, p. 225-230. http://dx.doi.org/10.1007/ s10750-007-9018-0

KEVREKIDIS, T. 2004. Seasonal Variation of the Macrozoobenthic Community Structure at Low Salinities in a Mediterranean Lagoon (Monolimni Lagoon, Northern Aegean). International Review of Hydrobiology, vol. 89, no. 4, p 407-425. http://dx.doi. org/10.1002/iroh.200310703 
MARQUES, MGSM., FERREIRA, RL. and BARBOSA, FAR. 1999. A comunidade de invertebrados aquáticos e características limnológicas das lagoas Carioca e da Barra, Parque Estadual do Rio Doce, MG. Revista Brasileira de Biologia, vol. 59, no. 2, p. 203-210. http://dx.doi.org/10.1590/S003471081999000200004

MORETTI, MS. and CALLISTO, M. 2005. Biomonitoring of benthic macroinvertebrates in the middle Doce River watershed. Acta Limnologica Brasiliensis, vol 17, p. 267-282.

MUGNAI, R., NESSIMIAN, JL. and BAPTISTA, DF. 2010. Manual de identificação de macroinvertebrados aquáticos do Estado do Rio de Janeiro. Rio de Janeiro:Technical Books. 176 p.

PAMPLIN, PAZ., ALMEIDA, TCM. and ROCHA, O. 2006. Composition and distribution of benthic macroinvertebrates in Americana Reservoir (SP, Brazil). Acta Limnologica Brasiliensis, vol. 19, no. 4, p. 439-452.

PAMPLIN, PAZ. and ROCHA, O. 2007. Temporal and bathymetric distribution of benthic macroinvertebrates in the Ponte Nova Reservoir, Tietê River (São Paulo, Brazil). Acta Limnologica Brasiliensis, vol. 18, no. 2, p. 121-132.

PECH, D, ARDISSON, PL. and HERNANDÉZGUEVARA, NA. 2007. Benthic community response to habitat variation: a case of study from a natural protected area, the Celestum coastal lagoon. Continental Shelf Research, vol. 27, p. 2,523-2,533.

PEREIRA, D. and DE LUCA, SJ. 2003. Benthic macroinvertebrates and the quality of the hydric resources in Maratá Creek basin (Rio Grande do
Sul, Brazil). Acta Limnologica Brasiliensia, vol. 15, no. 2, p. 57-68.

RICKLEFS, RE. and SCHLUTER, D. 1993. Species diversity: regional and historical influences. In RICKLEFS, RE. and SCHLUTER, D., orgs. Species diversity in ecological communities: historical and geographical perspectives. Chicago: University of Chicago Press. p. 350-363.

STRIXINO, G. and TRIVINHO-STRIXINO, S. 2006. Herptobentos e haptobentos de lagoas marginais da Estação Ecológica de Jataí (Luiz Antônio, SP). In SANTOS, JE., PIRES, JSR. and MOSCHINI, LE., orgs. Estudos integrados em ecossistemas - Estação Ecológica de Jataí. São Carlos: Edufscar. vol. 4, 417 p.

SUGUIO, K. 1973. Introdução à Sedimentologia. São Paulo: Edgard Blucher. 317 p.

TRIVINHO-STRIXINO, S. and STRIXINO, G. 1995. Larvas de Chironomidae (Diptera) do Estado de São Paulo. Guia de identificação e diagnose dos gêneros. São Carlos: Universidade Federal de São Carlos. 130 p. [Dissertação de Mestrado em Ecologia e Recursos Naturais].

WÜRDIG, NL., CENZANO, CSS. and MOTTAMARQUES, D. 2007. Macroinvertebrate communities structure in different environments of the Taim Hydrological System in the state of Rio Grande do Sul, Brazil. Acta Limnologica Brasiliensis, vol. 19, no. 4, p. 427-438.

WÜRDIG, NL., OZÓRIO, CP., RODRIGUES, GG. and WIEDENBRUG, S. 1998. The influence of environmental parameters in the structure of the benthic community in coastal lakes and lagoons of Rio Grande do Sul, Brasil. Internationalen Verein Limnologie, vol. 26, p. 1,514-1,517. 